\title{
COVID IMPACT ANALYSIS ON THE DYNAMICS OF DEVELOPMENT OF THE COUGH, COLD AND ALLERGY REMEDIES SEGMENT IN UKRAINE
}

\author{
${ }^{\odot 2021}$ NEZHYVA M. 0., MYSIUK V. 0.
}

UDC 338.24.021.8

JEL: D78; F52; H83; 110; 111; 118

\section{Nezhyva M. O., Mysiuk V. O. COVID Impact Analysis on the Dynamics of Development of the Cough, Cold and Allergy Remedies Segment in Ukraine}

Creating a competitive medical industry in Ukraine, which is based on economic, market principles of modern management and marketing, which will meet the socio-economic and political changes that have occurred recently in Ukraine and continue to this day is the main goal of modern medicine. It is necessary to create such a system of medical care, the functioning of which in Ukraine, on the one hand, will improve the quality of health care standards, and on the other - will improve the state of the health care system and health workers. The biggest problems in the direction of research are: panic-buying increases sales of cough, cold and allergy (hay fever) remedies despite competition from natural treatment initiative; self-medication will continue, as visiting a doctor is considered a last resort; fragmentation continues with local companies leading through lower prices. The aim of the article is to study the trends of cough, cold and allergy remedies in Ukraine and identify the impact of COVID-19 on such segment development. The article examines the medical field and the impact of COVID-19 on its development. Particular attention is paid to the development of such segments as cough, cold and allergy remedies in Ukraine. It was determined that consumers continued the tradition of self-medication during COVID-19, but the pandemic intensified the growth of panic. Retail prices for coughs, colds and allergy remedies are rising. It has been determined that sales of cough, cold and allergy remedies will increase by $8 \%$ of the current CAGR value.

Keywords: analysis, cough, cold, allergy, remedies, medicals, segment.

DOI: https://doi.org/10.32983/2222-4459-2021-7-281-288

Fig.: 6. Bibl.: 12.

Nezhyva Mariia 0. - PhD (Economics), Associate Professor of the Department of Financial Analysis and Audit, Kyiv National University of Trade and Economics (19 Kioto Str., Kyiv, 02156, Ukraine)

E-mail:marijka@ukr.net

ORCID: https://orcid.org/0000-0002-3008-5338

Researcher ID: https://publons.com/researcher/1460798/mariia-nezhyva/

Scopus Author ID: $h$ ttps://www.scopus.com/authid/detail.uri?authorld=57216845011

Mysiuk Viktoriia 0. - PhD (Economics), Senior Lecturer of the Department of Financial Analysis and Audit, Kyiv National University of Trade and Economics (19 Kioto Str., Kyiv, 02156, Ukraine)

E-mail:mysuk091@ukr.net

ORCID: https://orcid.org/0000-0001-8931-7335

Researcher ID: https://publons.com/researcher/3092902/viktoriia-mysiuk/

\section{УДК 338.24.021.8}

JEL: D78; F52; H83; I10; I11; 118

Нежива М. О., Мисюк В. О. Аналіз впливу COVID на динаміку розвитку сегмента лікарських засобів проти кашлю, застуди та алергії в Україні Створення конкурентоспроможної медичної галузі в Україні, яка базується на економічних, ринкових принципах сучасного менеджменту та маркетингу, що буде відповідати соціально-економічним і політичним змінам, що відбулися нещодавно в Україні та триватимуть донині, єголовною метою сучасної медицини. Необхідно створити таку систему медичної допомоги, функціонування якої в Україні, поліпшить, з одного боку, якість стандартів охорони здоров'я, а з іншого - стан системи охорони здоров'я та медичних працівників. Найбільшими проблемами в напрямку досліджень є такі: панічна купівля збільшує продажі ліків від кашлю, застуди та алергії; самолікування буде продовжуватися, оскільки відвідування лікаря вважається крайнім заходом; фрагментація продовжується з місцевими компаніями через зниження цін. Метою статтіє вивчення тенденцій лікування кашлю, застуди та алергії в Україні та виявлення впливу COVID-19 на розвиток даного сегмента. У статті досліджено медичну галузь і вплив на їі розвиток COVID-19. Особливу увагу приділено розвитку таких сегментів, як засоби від кашлю, застуди та алергії в Україні. Визначено, що споживачі продовжили традицію самолікування під час COVID-19, проте пандемія посилила зростання паніки. Ціни на засоби від кашлю, застуди та алергії в роздрібній торгівлі зростають. Визначено, що обсяг продажів засобів від кашлю, застуди та алергії зросте на 8\% від поточного значення CAGR.

Ключові слова: аналіз, кашель, застуда, алергія, засоби, медикаменти, сегмент.

Рис.: 6. Бібл.: 12.

Нежива Марія Олександрівна - кандидат економічних наук, доцент кафедри фінансового аналізу та аудиту, Київський національний торговельно-економічний університет (вул. Кіото, 19, Київ, 02156, Україна)

E-mail:marijka@ukr.net

ORCID: https://orcid.org/0000-0002-3008-5338

Researcher ID: $h$ ttps://publons.com/researcher/1460798/mariia-nezhyva/

Scopus Author ID: https://www.scopus.com/authid/detail.uri?authorld=57216845011

Мисюк Вікторія Олександрівна - кандидат економічних наук, старший викладач кафедри фінансового аналізу та аудиту, Київський національний торговельно-економічний університет (вул. Кіото, 19, Київ, 02156, Україна)

E-mail:mysuk091@ukr.net

ORCID: https://orcid.org/0000-0001-8931-7335

Researcher ID: https://publons.com/researcher/3092902/viktoriia-mysiuk/ 
C reating a competitive medical industry in Ukraine, which is based on economic and market principles of modern management and marketing, which will meet the socio-economic and political changes that have occurred recently in Ukraine and continue to this day. is the main goal of modern medicine. It is necessary to create such a system of medical care, the functioning of which in Ukraine will improve the quality of health care standards, on the one hand, and-the state of the health care system and health workers, on the other.

The biggest problems in the research area are the following: panic-buying increases sales of cough, cold and allergy (hay fever) remedies despite competition from natural treatment initiative; self-medication continues, as visiting a doctor is considered a last resort; fragmentation continues with local companies leading through lower prices.

Analysis of recent research and publications. Significant attention to the development dynamics and financial security of health care in Ukraine is paid in the scientific works of many scientists. A. Bairak, L. Voievoda [1] explore the main problems of health care system development, considers the features of instruments for regulating and financing the institution of public-private partnership in the field of health care. The author argues that to address the financial problems of creating and operating strategically important facilities for socio-economic development of society in a budget deficit, it is necessary to introduce public-private partnership in Ukraine. V. Ievtushenko [2] analyzes the main mechanisms of the state regulation of medicine, namely legal, social, monitoring, economic, organizational, personnel, motivational, market regulation, which largely determine the effectiveness of medicine in Ukraine. The author proposes to strengthen the relevant mechanism of public administration in order to continue the effective development of folk medicine in Ukraine. T. Zhiber, T. Solopenko [3] explore the issue of achieving the effectiveness of program-targeted budgeting based on the requirements of the current Budget Code of Ukraine. The researcher identifies efficiency components, which, in turn, are grouped by operational and economic efficiency. N. Karpyshyn, I. Sydor [4] explore the peculiarities of financing medical services in foreign countries and Ukraine. They believe that a health care reform should be aimed at legal, institutional and financial transformations to improve access to health care and reduce the financial burden on citizens' budgets. L. Kvasniy et al. [5] explores the peculiarities of the new rules for financing health care facilities in Ukraine during the medical reform period. S. Kushnir, A. Onipko [6] analyze the volume and dynamics of the structure of health care financing in Ukraine, the main types of free and paid medical services defined by laws and regulations acting in Ukraine. Authors consider the process of transition to a new system of financing medical care for patients. L. Parkheta [7] analyzes the dynamics of budget funding for health care and social protection, considers the prob- lems that hinder the introduction and development of insurance medicine in Ukraine and outlines the main tasks of health insurance in the system of social protection. M. Povoroznyk [8] examines the dynamics of total health care expenditures in Ukraine, analyzes the effectiveness of the structural distribution of the total costs of financing the health care system, and identifies the financing system asymmetry and imbalances in the provision of medical services. K. Chernenok, H. Semenenko, O. Lukonin [9] study the financial state of a medical institution as for changing the principles of financing its activities. They analyze the main and additional sources of attracting financial support for a medical institution in the context of its transition to the status of a municipal nonprofit enterprise. K. Yahelska [10] considers the world experience of the organization of health care financing systems and the stages of reforming the domestic model of medical services. T. Yamnenko, A. Zheliak [11] define the term "folk and alternative medicine", explore the mechanism of legal regulation and the process of financing folk and alternative medicine. However, scientists do not pay enough attention to the COVID impact analysis of the development dynamics of the cough, cold and allergy segment in Ukraine.

The aim of the article is to study the trends of cough, cold and allergy remedies in Ukraine and identify the impact of COVID on the segment development.

The research was carried out using the following methods: monographic - to generalize the theoretical and methodological foundations of segments development; analysis and synthesis, induction and deduction to state the problem under research, to detail and clarify its subject; system analysis - to clarify the essence of concepts; classification-analytical - to classify segments; graphic - for visual and schematic representation of theoretical and practical results of research and questionnaires. The information base of the study is monographic literature, norms and regulations of Ukraine, periodicals, and information from the Internet.

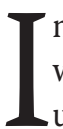
n 2020 cough, cold and allergy (hay fever) remedies will benefit from Ukrainians panic-buying such products, fearing shortages during the COVID-19 lockdown. This is despite the worsening economic situation and weakening consumer spending power. Ukrainians typically self-medicate, visiting the doctor as a last resort, and this tradition did not alter during the outbreak of COVID-19, with consumers being advised to stay at home to combat the spread.

Cough, cold and allergy (hay fever) remedies are more commonly purchased in chemists/pharmacies where consumers sometimes seek a pharmacist's advice. E-commerce cannot fully realise its potential in Ukraine, despite consumers staying at home due to COVID-19, since it is illegal to purchase OTC via e-commerce channels. However, online stores have found ways to over- 
come such regulations, for example by allowing consumers to pre-order OTC medicines rather than buying them outright. This allows chemists/pharmacies to compete with the recent public initiative of promoting "natural" treatment of colds. This initiative recommends Ukrainians treat themselves not by chemicals or antibiotics, but by home-made remedies, such as drinking lots of water or hot teas to moisturise the nasal passage - this particular treatment has been greatly publicised by the celebrity paediatrician Ye. Komarovsky. Sales of cough, cold and allergy (hay fever) remedies, by region inclusively, are shown in Fig. 1 and Fig. 2.

$O^{2}$ elf-medication of coughs, colds and, to a lesser extent, allergies remains high in Ukraine (Fig. 3). Many Ukrainians do not have a flu vaccine, as in addition to problems with regular supplies of flu vaccines in recent years, many people resist vaccination, in general. This maintains a high level of flu in the country, in addition to more everyday coughs and colds. In the event of catching a cough, cold or flu, Ukrainians typically consider self-medication as the first line of defence.
In less complicated cases, cough remedies are purchased based on prior experience or pharmacists' advice. Advertisements for cough, cold and allergy (hay fever) remedies on television, such as Ambrobene and Edem, contribute to consumer awareness of specific products for different purposes. In fact, self-medicating with antibiotics is common even amongst children, as local doctors recommend them "just to be on the safe side". Pharyngeal preparations is the biggest category within cough, cold and allergy (hay fever) remedies in 2020 as sore throats are usually treated at home both for adults and children. Decongestants is another popular category, with sprays becoming increasingly popular in recent years due to their convenience. Young and middle-aged Ukrainians are typically attracted to using combination products since they can be used on-the-go and allow consumers to continue going to work when the illness is not too serious.

With a wide assortment of cough, cold and allergy (hay fever) remedies available from both local and international players, the competitive landscape is highly fragmented in Ukraine. Multinational companies, led by Engelhard Arzneimittel, Sandoz Ukraine, Bayer and

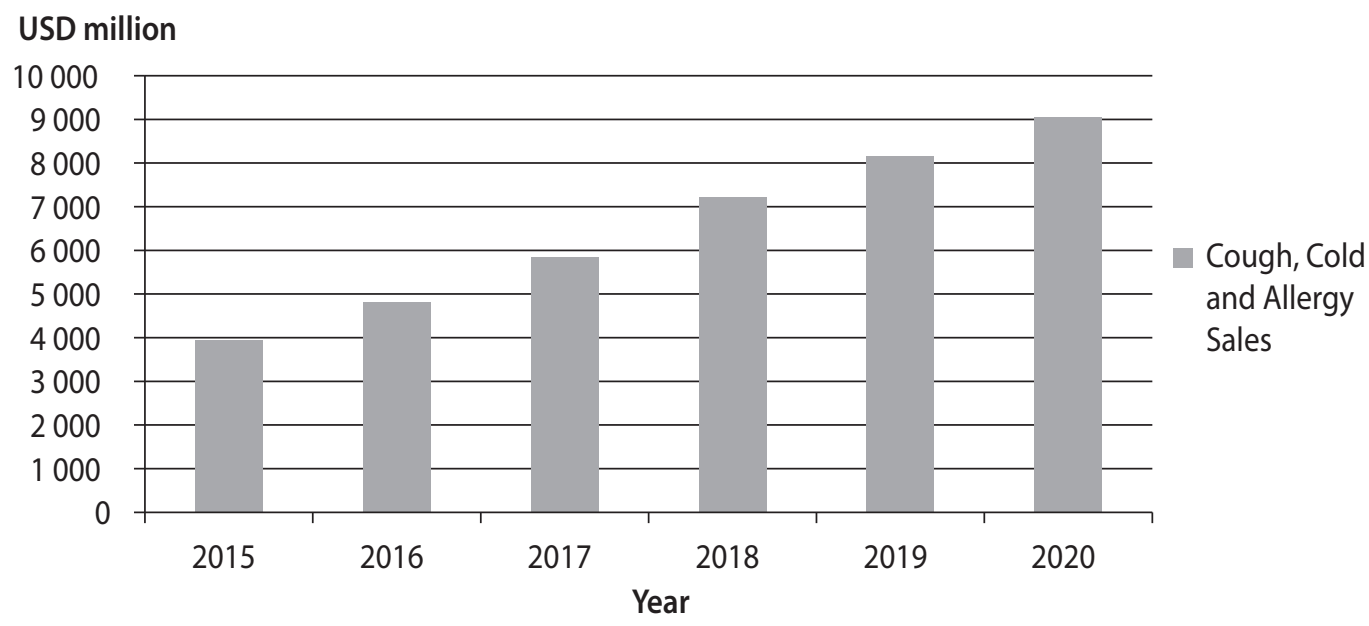

Fig. 1. Sales of Cough, Cold and Allergy (Hay Fever) Remedies (USD million)

Source: developed by the authors on the basis of [12].

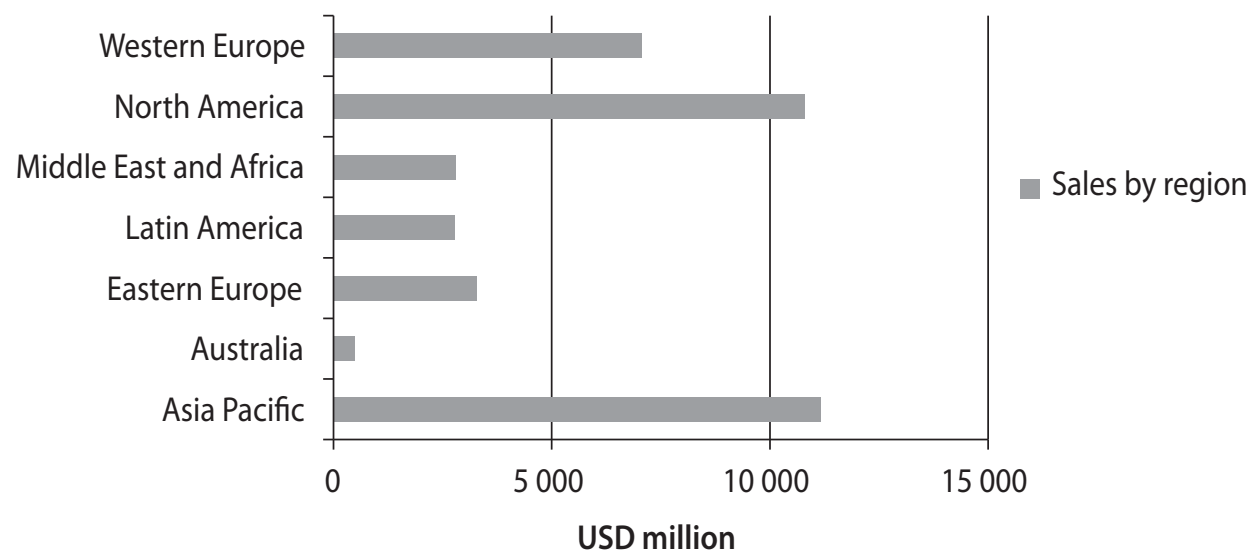

Fig. 2. Cough, Cold and Allergy Remedies Retail Sales by Region (USD million)

Source: developed by the authors on the basis of [12]. 


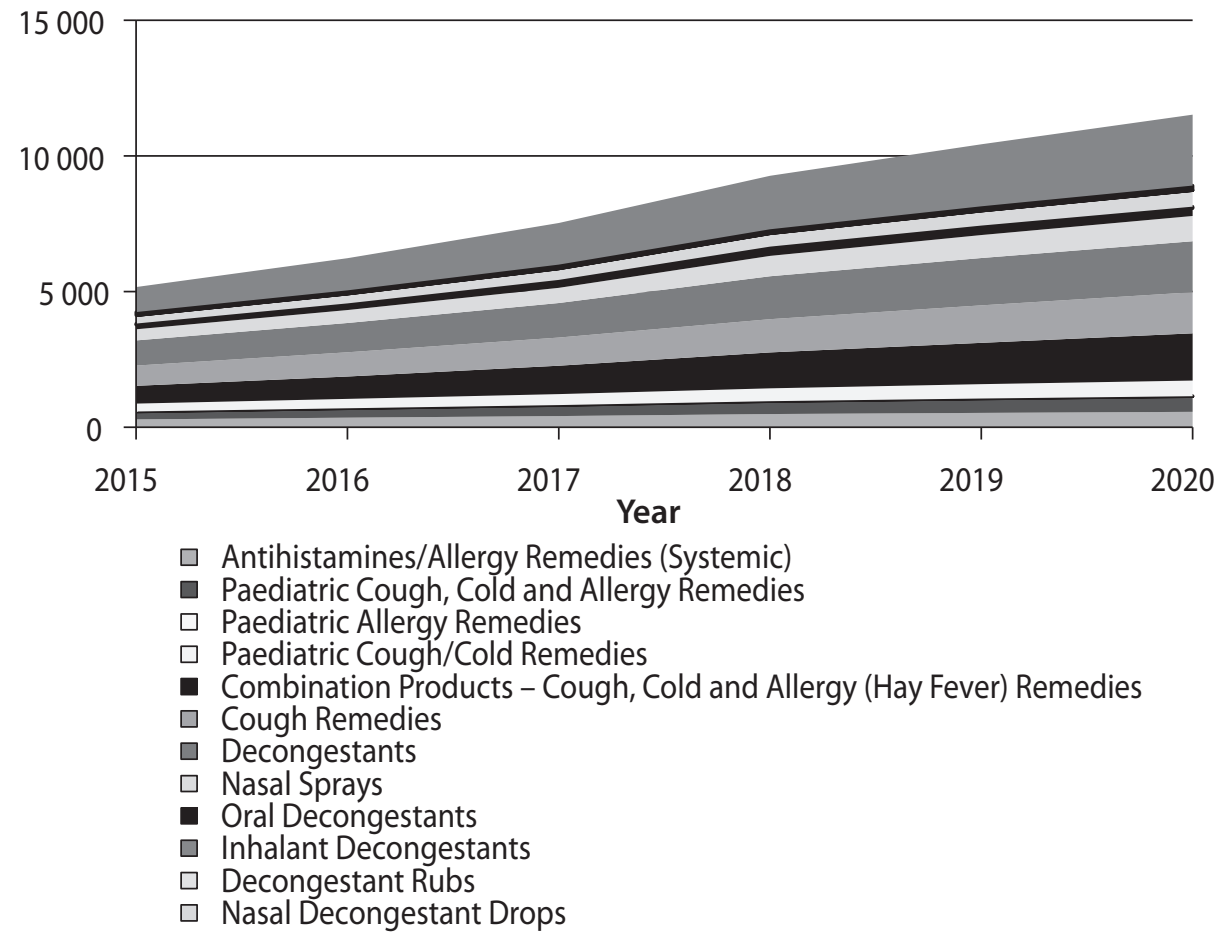

Fig. 3. Sales of Cough, Cold and Allergy (Hay Fever) Remedies by Category (USD million Growth Performance) Source: developed by the authors on the basis of [12].

GlaxoSmithKline Pharmaceuticals Ukraine are stronger than domestic companies in current value terms due to higher prices and a well-established presence. They experience strong consumer loyalty with their branded medicines, such as Theraflu, Coldrex, Trachisan, Prospan and Health Life. Sales of international brands such as Strepsils and Prospan are high due to their efficiency, as well as high investment in advertising support, especially via national television channels, thus driving high consumer loyalty in Ukraine.

$\mathrm{H}$ owever, the lead in 2020 is held by the local company Farmak, which attracts consumers with its wide assortment of decongestants, as well as the antihistamine Edem and its flagship brand Eucazolin Aqua, which is popular due to its spray packaging format and extensive promotional support from the company. It also benefits from targeting Ukrainians with lower prices than international brands. Local manufacturers of cough, cold and allergy (hay fever) remedies typically have a wide portfolio, including generic offers such as Amroxol, Mukaltin and Pertussin, and appeal to consumers with more competitive prices compared with imported offers.

The change in the value of the company's shares of cough, cold and allergy remedies is shown in Fig. 4. The market is ambiguous. Some companies are improving their operations, sales and business value, while others are obtaining worse results.

Over the forecast period, cough, cold and allergy (hay fever) remedies are expected to continue to benefit from a strong reliance on self-medication for coughs and colds. In Ukraine, there is a strong tradition of self-medication with consumers preferring to treat themselves with OTC medicines and only visiting the doctor as a last resort. As a result, current value growth for cough, cold and allergy (hay fever) remedies is expected to remain strong over the forecast period, although lower than the growth seen in the review period. Brand shares of cough, cold and allergy remedies are shown in Fig. 5.

$\mathrm{I}$ $\mathrm{n}$ the late review period, the Ministry of Health started an initiative to highlight the appropriateness (or otherwise) of different treatments for coughs, colds and flu and has published recommendations on efficient and less efficient medicines for such conditions.

For instance, it is concerned about the consumption of antibiotics and mucolytics for self-medication, as it states these are not necessary. Other medicines on the list of those advised not to be taken for coughs, colds and flu include interferon, cough syrups (which can be harmful for children under four), antivirals (except for Ozeltamivir and Zanamivir), vitamins, combination cough and cold medicines, antihistamines and herbal preparations. However, this initiative is unlikely to have a negative effect on sales of cough, cold and allergy (hay fever) remedies over the forecast period, as many Ukrainians are unhappy with the state of the health service and prefer not to waste their precious time visiting a doctor.

Whilst at the end of the review period consumers still economized following the crises of 2014 and 2015, 


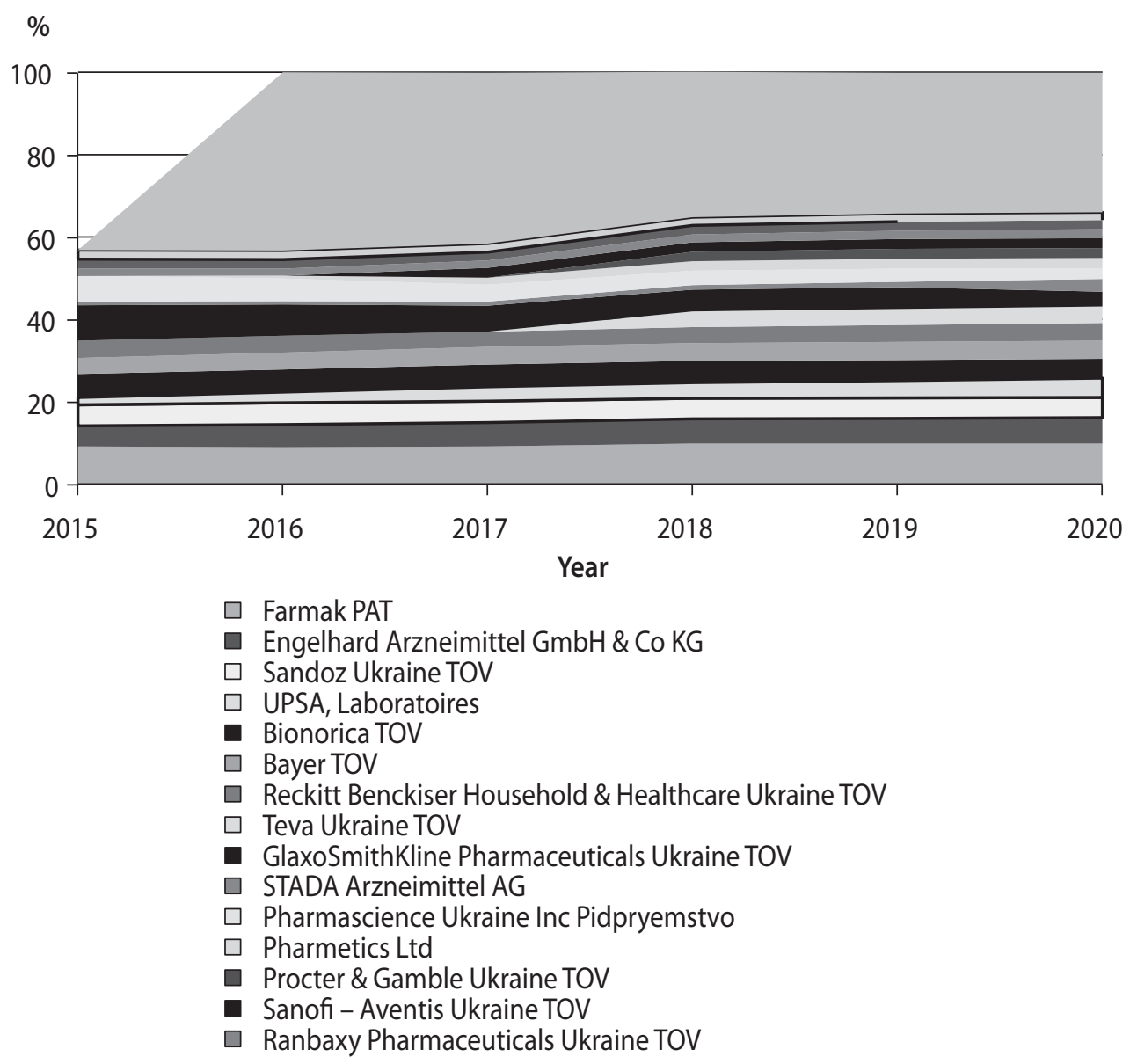

Fig. 4. Company Shares of Cough, Cold and Allergy Remedies (\% Share - Retail Value 2020) Source: developed by the authors on the basis of [12]

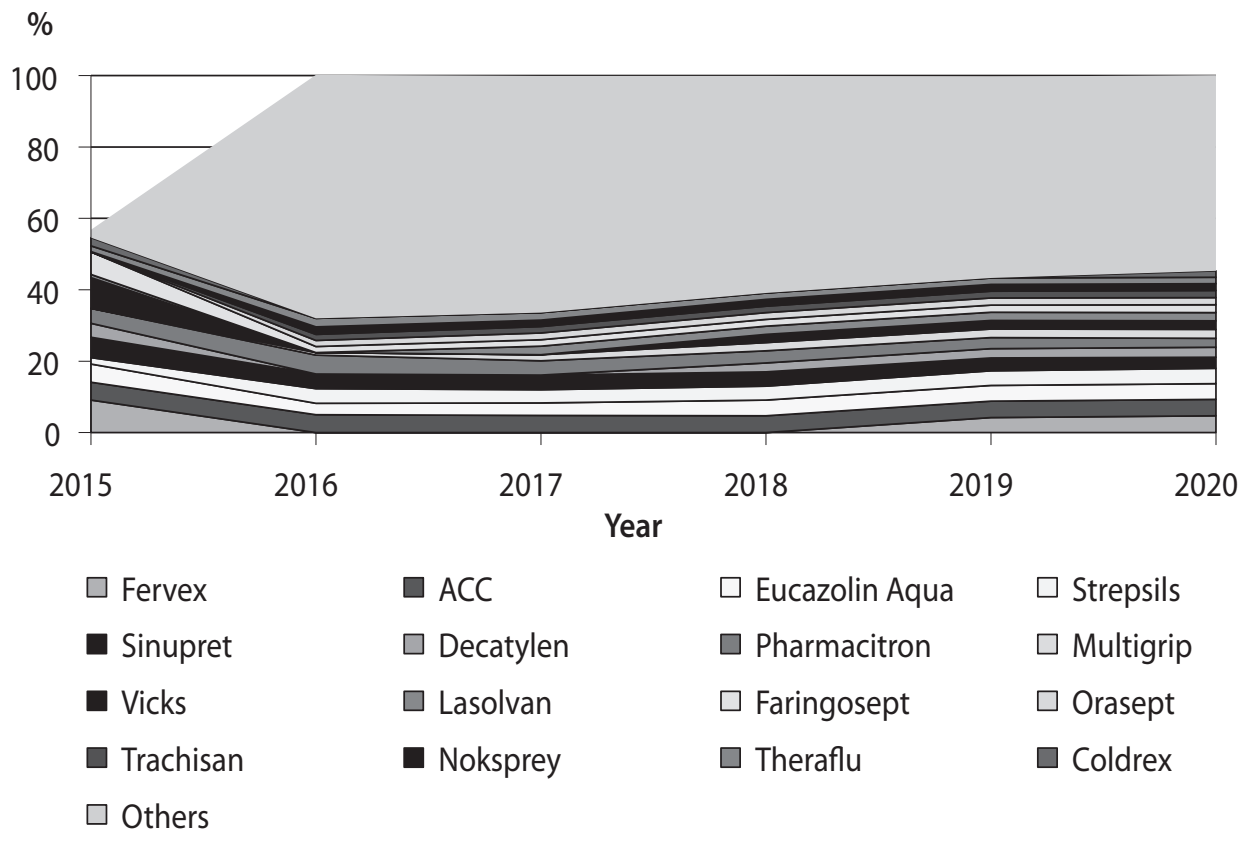

Fig. 5. TOP 10 Brand Shares of Cough, Cold and Allergy Remedies (\% Share - Retail Value 2020) Source: developed by the authors on the basis of [12]. 
growth in consumers' incomes will allow for higher spending on cough, cold and allergy (hay fever) remedies in the forecast period. Ukraine suffers from poor environmental conditions, with polluted water and air, as well as wide penetration of unhealthy ingredients in food, such as glutamate natrium and preservatives. These factors diminish consumers' immunity and contribute to higher incidences of allergies. Abuse of antibiotics is also believed to be resulting in the further spread of allergies. As such more attention will be paid to the efficacy of the medicine rather than pricing. Environmental factors are not expected to see much improvement over the forecast period, thus antihistamines/allergy remedies are expected to continue to see growth.

Cough, cold and allergy (hay fever) remedies are actively developing in relation to selected industries FMCG (Fig. 6). the branding of their medicines, with larger companies expected to increase their competitive edge by investing in advertising during the forecast period. As consumers' incomes have continued to rise over the review period, efficacy of cough, cold and allergy (hay fever) remedies is increasingly considered to be a more important factor than price, thus, international brands are expected to see rising shares, leading to greater concentration and less focus on price wars. Old-fashioned cheaper medicines such as Lugolis, an inhalant decongestant, are expected to continue losing their appeal.

\section{CONCLUSIONS}

Under the impact of COVID-19, cough, cold and allergy segments have changed the development dynamics and resulted in the following: consumers continued a tradition of self-medicine during the COVID-19 lock-

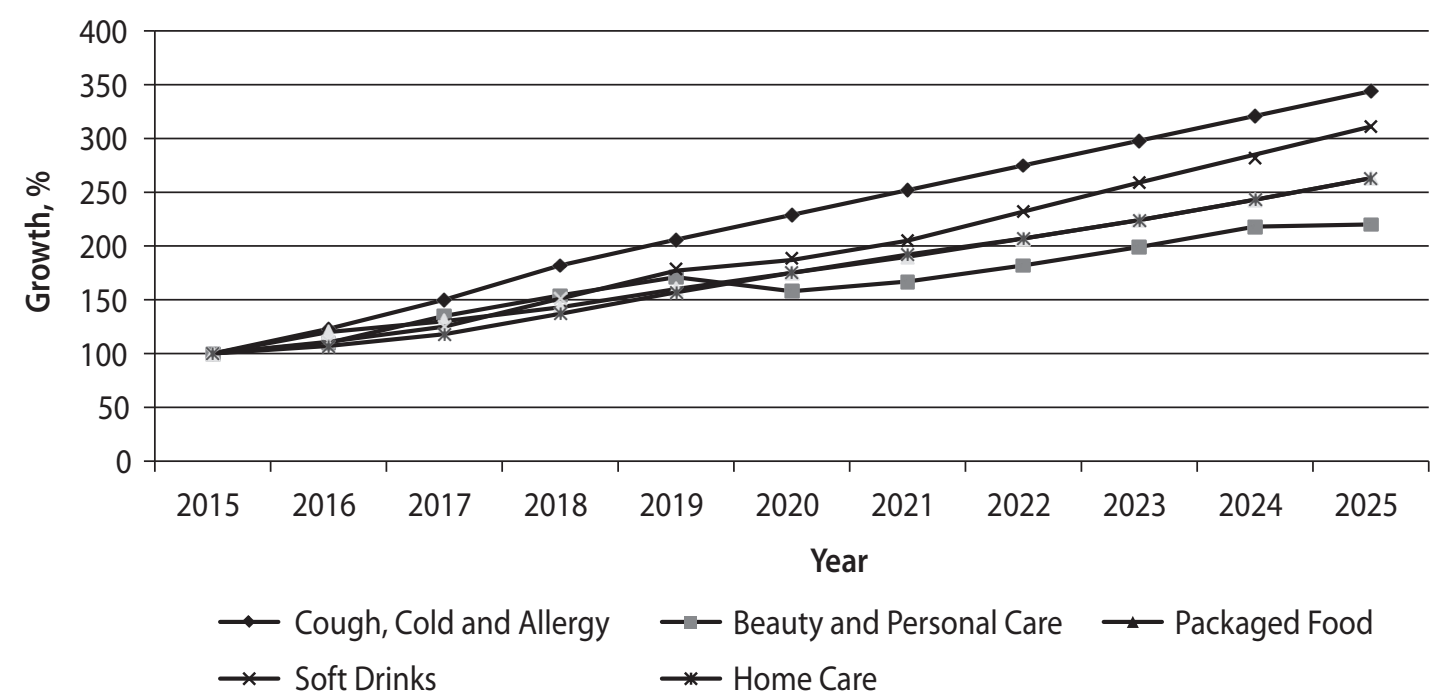

Fig. 6. Cough, Cold and Allergy (Hay Fever) Remedies vs Selected FMCG Industries

Source: developed by the authors on the basis of [12].

Innovations are set to be a driving force for growth in cough, cold and allergy (hay fever) remedies in the forecast period. In the late review period, new product development was considered by manufacturers, with the focus on novel approaches. For instance, Eslotin from World Medicine was launched among systemic antihistamines/ allergy remedies. It contains loratadine, which is considered a very effective antihistamine, as well as the one having an antiinflammatory effect. It also lacks the sedative effect of older treatments and has a longer-term effect.

In addition, Arterium Corporation launched two new nasal sprays with different actions in 2019. Narivent reduces swelling and has an anti-inflammatory effect, whilst Rhinosermin forms a biological barrier against disease-causing microorganisms in the nasal passage. Darnitsa launched Rinazal, which is a fast-acting, long-lasting nasal spray, which does not cause dryness and irritation.

Manufacturers of cough, cold and allergy (hay fever) remedies increasingly place a greater emphasis on down in 2020, with cough, cold and allergy (hay fever) remedies experiencing growth due to panic-buying; cough, cold and allergy (hay fever) remedies record 11\% retail current value growth to reach UAH9.1 billion in 2020; combination products (cough, cold and allergy (hay fever) remedies and pharyngeal preparations) are the fastest growing category in 2020, rising by $14 \%$ to reach UAH1.7 billion and UAH2.6 billion respectively; Farmak continues to lead cough, cold and allergy (hay fever) remedies in 2020 with a retail value share of $10 \%$; value sales of cough, cold and allergy (hay fever) remedies are expected to rise at a $8 \%$ current value CAGR (3\% constant 2020 value CAGR) over the forecast period.

\section{LITERATURE}

1. Байрак А. О., Воєвода Л. Г. Дослідження інструментарію регулювання та фінансування інституту державно-приватного партнерства у медичному 
секторі. Менеджер. Серія «Економіка». 2020. № 3. C. 131-140.

DOI: 10.35340/2308-104X.2020.88-3-13

2. Євтушенко В. В. Народна медицина як складова традиційної української культури. Вісник Національної академії державного управління при Президентові України. Серія «Державне управління». 2019. № 3. C. 91-97.

DOI: 10.36030/2310-2837-3(94)-2019-91-97

3. Жибер Т. В., Солопенко Т. В. Сутнісно-правові аспекти визначення складових показника ефективності бюджетної програми на прикладі фінансування вторинної ланки медичної допомоги. Економічний вісник. Серія «Фінанси, облік, оподаткування». 2020. Вип. 5. С. 88-97.

DOI: https://doi.org/10.33244/2617-5932.5.2020.88-97

4. Карпишин Н. І., Сидор І. П. Фінансування медичних послуг: досвід зарубіжних країн і України. Економіка. Фінанси. Право. 2020. № 8. С. 9-13.

DOI: https://doi.org/10.37634/efp.2020.8.2

5. Квасній Л. Г., Щербан О. Я., Романів О. В., Попадинець Н. М. Сучасні форми фінансування закладів охорони здоров'я в Україні в контексті медичної реформи. Вісник Сумського національного аграрного університету. Серія «Економіка і менеджмент». 2019. Вип. 4. С. 144-148.

DOI: 10.36030/2310-2837-3(94)-2019-91-97

6. Кушнір С. О., Оніпко А. Д. Медична реформа в Україні - проблеми фінансування, аналіз перспектив та наслідків. Економічний простір. 2018. № 132. C. 61-71.

DOI: $10.30838 /$ P.ES.2224.240418.61.51

7. Пархета Л. В. Страхова медицина як альтернативна модель організації охорони здоров'я в Україні. Стратегія економічного розвитку України. 2017. Вип. 41. С. 186-192. URL: https://ir.kneu. edu.ua/bitstream/handle/2010/23477/186-192. pdf? sequence $=1$ \&isAllowed $=y$

8. Поворозник М. Ю. Асиметричність фінансування охорони здоров'я у контексті формування ефективності надання медичних послуг за міжнародними стандартами. Науковий вісник Херсонського державного університету. Серія «Економічні науки». 2018. Вип. 29. Ч. 1. С. 60-64. URL: http://ej.journal.kspu.edu/ index.php/ej/article/view/163/159

9. Черненок К. П., Семененко Г. М., Луконін О. В. Оцінка фінансового стану медичного закладу в умовах реформи фінансування системи охорони здоров'я. Ефективна економіка. 2020. № 12.

DOI: 10.32702/2307-2105-2020.12.105

10. Ягельська К. Ю. Організаційно-економічні особливості трансформаційної моделі охорони здоров'я України. Вчені записки Таврійського начіонального університету імені В. І. Вернадського. Серія «Економіка іуправління». 2020. Т. 31. № 6. С. 83-88. DOI: https://doi.org/10.32838/2523-4803/70-6-14

11. Ямненко Т. М., Желяк А. А. Народна та нетрадиційна медицина в Україні: механізм правового регулювання. Наукові праці Національного авіаційного університету. Серія «Юридичний вісник «Повітряне і космічне право». 2020. № 1. С. 135-140.

DOI: https://doi.org/10.18372/2307-9061.54.14551

12. Euromonitor International. URL: https://www.portal. euromonitor.com/portal/analysis/tab

\section{REFERENCES}

Bairak, A. O., and Voievoda, L. H. "Doslidzhennia instrumentariiu rehuliuvannia ta finansuvannia instytutu derzhavno-pryvatnoho partnerstva u medychnomu sektori" [Research Instrumentation Management and Financing of the Institute for Public-Private Partnership in Medical Sector]. Menedzher. Seriia «Ekonomika», no. 3 (2020): 131-140.

DOI: 10.35340/2308-104X.2020.88-3-13

Chernenok, K. P., Semenenko, H. M., and Lukonin, O. V. "Otsinka finansovoho stanu medychnoho zakladu $\mathrm{v}$ umovakh reformy finansuvannia systemy okhorony zdorov'ia" [Assessment of the Financial Condition of a Medical Institution in the Context of Healthcare Financing Reform]. Efektyvna ekonomika, no. 12 (2020). DOI: 10.32702/2307-2105-2020.12.105

Euromonitor International. https://www.portal.euromonitor.com/portal/analysis/tab

Karpyshyn, N. I., and Sydor, I. P. "Finansuvannia medychnykh posluh: dosvid zarubizhnykh krain i Ukrainy" [Financing of Medical Services: Experience of Foreign Countries and Ukraine]. Ekonomika. Finansy. Pravo, no. 8 (2020): 9-13.

DOI: https://doi.org/10.37634/efp.2020.8.2

Kushnir, S. O., and Onipko, A. D. "Medychna reforma v Ukraini - problemy finansuvannia, analiz perspektyv ta naslidkiv" [Healthcare Reform in Ukraine - Issue of Financing, Examination of Prospects and Consequenses]. Ekonomichnyi prostir, no. 132 (2018): 61-71. DOI: 10.30838/ P.ES.2224.240418.61.51

Kvasnii, L. H. "Suchasni formy finansuvannia zakladiv okhorony zdorovia v Ukraini v konteksti medychnoi reformy" [Contemporary Forms of Healthcare Facilities Funding in Ukraine in the Context of the Healthcare Reform]. Visnyk Sumskoho natsionalnoho ahrarnoho universytetu. Seriia «Ekonomika i menedzhment», no. 4 (2019): 144-148. DOI: 10.36030/2310-2837-3(94)-2019-91-97

Parkheta, L. V. "Strakhova medytsyna yak alternatyvna model orhanizatsii okhorony zdorovia v Ukraini" [Insurance Medicine as an Alternative Model of Health Organization in Ukraine]. Stratehiia ekonomichnoho rozvytku Ukrainy, is. 41 (2017): 186-192. https://ir.kneu. edu.ua/bitstream/handle/2010/23477/186-192. pdf? sequence $=1$ \&isAllowed $=y$

Povoroznyk, M. Yu. "Asymetrychnist finansuvannia okhorony zdorovia u konteksti formuvannia efektyvnosti nadannia medychnykh posluh za mizhnarodnymy standartamy" [Healthcare Financing Asymmetry in the Context of Medical Servives Effective Provision under International Standards]. Naukovyi visnyk Khersonskoho derzhavnoho universytetu. Seriia «Ekonomichni nauky», is. 29, part 1 (2018): 60-64. http://ej.journal. kspu.edu/index.php/ej/article/view/163/159

Yahelska, K. Yu. "Orhanizatsiino-ekonomichni osoblyvosti transformatsiinoi modeli okhorony zdorovia Ukrainy" [Organizational and Economic Features of the Transformation Model of Healthcare of Ukraine]. Vcheni zapysky Tavriiskoho natsionalnoho universytetu imeni V. I. Vernadskoho. Seriia «Ekonomika i upravlinnia», vol. 31, no. 6 (2020): 83-88.

DOI: https://doi.org/10.32838/2523-4803/70-6-14 
Yamnenko, T. M., and Zheliak, A. A. “Narodna ta netradytsiina medytsyna $v$ Ukraini: mekhanizm pravovoho rehuliuvannia" [Traditional and Non-traditional Medicine in Ukraine: Mechanism of Legal Regulation]. Naukovi pratsi Natsionalnoho aviatsiinoho universytetu. Seriia «Yurydychnyi visnyk «Povitriane i kosmichne pravo», no. 1 (2020): 135-140.

DOI: https://doi.org/10.18372/2307-9061.54.14551

Yevtushenko, V. V. "Narodna medytsyna yak skladova tradytsiinoi ukrainskoi kultury" [Traditional Medicine as a Component of Traditional Ukrainian Culture]. Visnyk Natsionalnoi akademii derzhavnoho upravlinnia pry
Prezydentovi Ukrainy. Seriia «Derzhavne upravlinnia», no. 3 (2019): 91-97.

DOI: 10.36030/2310-2837-3(94)-2019-91-97

Zhyber, T. V., and Solopenko, T. V. "Sutnisno-pravovi aspekty vyznachennia skladovykh pokaznyka efektyvnosti biudzhetnoi prohramy na prykladi finansuvannia vtorynnoi lanky medychnoi dopomohy" [Essential and Legal Aspects of Determining an Effectiveness Indicator of Budget Program Components by the Example of Secondary Level Medical Care Financing]. Ekonomichnyi visnyk. Seriia "Finansy, oblik, opodatkuvannia», no. 5 (2020): 88-97.

DOI: https://doi.org/10.33244/2617-5932.5.2020.88-97 